\title{
Essential oils in pathogen resistance induction of Eucalyptus benthamii Maiden et Cambage
}

\author{
Luma Dalmolin Stenger ${ }^{1,2}$ (D) Gabriela Libardoni ${ }^{1,3}$ Américo Wagner Júnior ${ }^{1}$ (i) Juliano Zanela AD $^{(\mathbb{C})}$ \\ Leonardo Tozzetti Alves ${ }^{1}$ (i) Gabriela Osowski Varpechoski ${ }^{1}$ (i) Everton Ricardi Lozano $^{1}$ (i) \\ Michele Potrich ${ }^{*}$ (D)
}

${ }^{1}$ Universidade Tecnológica Federal do Paraná (UTFPR), Campus Dois Vizinhos (DV), Laboratório de Controle Biológico, Dois Vizinhos, PR, Brasil. ${ }^{2}$ Programa de Pós-graduação em Agroecossistemas (PPGSIS), Universidade Tecnológica Federal do Paraná (UTFPR), 85660-000, Dois Vizinhos, PR, Brasil. E-mail: profmichele@gmail.com. *Corresponding author.

${ }^{3}$ Programa de Pós-graduação em Agronomia (PPGAG), Universidade Estadual de Londrina (UEL), Londrina, PR, Brasil.

ABSTRACT: This study evaluated the essential oils of Melaleuca alternifolia, Casearia sylvestris and Eugenia uniflora as inducers of defense mechanisms in Eucalyptus benthamii seedlings. Four $m L$ of each oil, with a concentration of $0.75 \%$ were sprayed in E. benthamii seedlings and two bioassays were performed, in the first, the essential oils were sprayed and after 30 days, sugars, proteins, peroxidases, phenylalanine ammonia (PAL), and phenols were evaluated and; in the second, seven days after the first analysis, the essential oils were again sprayed and after three days, the same variables were evaluated. The essential oils of M. alternifolia, C. sylvestris, and E. uniflora sprayed had no significant effects on E. benthamii seedlings after 30 days in terms of total sugars, proteins, peroxidase, PAL activity, and phenols. However, when M. alternifolia and E. uniflora essential oils were sprayed seven days after the first analysis with evaluation after 3 days, an increase in total sugars was observed. After these days, all essential oils promoted an increase in protein levels. The oils of E. uniflora and C. sylvestris also increased peroxidase levels. The PAL defense enzyme not showed increased when essential oils were used. The essential oils of M. alternifolia and C. sylvestris had potential as inducers of defense mechanisms on E. benthamii seedlings after 3 days of their application, what it demonstrated not be permanent.

Key words: biotic inductors, Melaleuca alternifolia, Casearia sylvestris, Eugenia uniflora.

Óleos essenciais na indução de resistência a patógenos em Eucalyptus benthamii Maiden et Cambage

RESUMO: Este trabalho teve como objetivo avaliar os óleos essenciais de Melaleuca alternifolia, Casearia sylvestris e Eugenia uniflora como indutores de mecanismos de defesa em mudas de Eucalyptus benthamii. Quatro $m L$ de cada óleo, com concentração de 0,75\%, foram pulverizados em mudas de E. benthamii e foram realizados dois bioensaios. No primeiro foram pulverizados os óleos essenciais e após 30 dias, açucares, proteinas, peroxidases, fenilalanina amônia (PAL) , e fenóis foram avaliados e; na segunda, sete dias após a primeira análise, os óleos essenciais foram novamente pulverizados e após três dias, as mesmas variáveis foram avaliadas. Os óleos essenciais de M. alternifolia, C. sylvestris e E. uniflora pulverizados não tiveram efeito significativo sobre as mudas de E. benthamii após 30 dias em termos de açúcares totais, proteínas, peroxidase, atividade PAL e fenóis. Entretanto, quando os óleos essenciais de M. alternifolia e E. uniflora foram pulverizados sete dias após a primeira análise com avaliação após três dias, foi observado um aumento nos açúcares totais. Depois desses dias, todos os óleos essenciais promoveram aumento nos niveis de proteinas. Os óleos de E. uniflora e C. sylvestris também aumentaram os niveis de peroxidase. A enzima de defesa PAL não se mostrou aumentada quando óleos essenciais foram usados. Os óleos essenciais de M. alternifolia e C. sylvestris apresentaram potencial como indutores de mecanismos de defesa em mudas de E. benthamii após três dias de sua aplicação, o que demonstrou não ser permanente.

Palavras-chave: indutores bióticos, Melaleuca alternifolia, Casearia sylvestris, Eugenia uniflora.

\section{INTRODUCTION}

The genus Eucalyptus one of the most cultivated forest species in Brazil and occupies 5.56 million hectares, representing $71.9 \%$ of the total cultivation area (IBÁ, 2015). Eucalyptus dunnii (Maiden), E. saligna (Smith), E. grandis (Hill) and E. benthamii (Maiden et Cambage) are the species with the highest economic importance.

The expansion of the eucalyptus plantation area throughout the country, mainly with clonal trees, is increasing in the incidence of insect pests. Among them is the species Thaumastocoris peregrinus (CARPINTERO \& DELLAPÉ), 2006 
(Hemiptera: Thaumastocoridae), originally from Australia, but with occurrence in African and European countries (JACOBS \& NESER, 2005; CARPINTERO \& DELLAPÉ, 2006; MARTÍNEZ \& BIANCHI, 2010; WILCKEN et al., 2010; IDE et al., 2011; SOPOW et al., 2012; GARCIA et al., 2013; JIMNEZ-QUIROZ et al., 2016; MACHADO et al., 2019; CASTIGLIONE et al., 2020; MACHADO et al., 2020). It was first registered in Brazil in 2008, spreading rapidly throughout all regions of the country. It causes significant damage to eucalypt stands, with substantial economic losses (GARCIA et al., 2013; LORENCETTI et al., 2015).

Thaumastocoris peregrinus is a pest insect with high reproductive capacity and it is characterized by its rapid infestation in commercial eucalypt plantations (JACOBS \& NESSER, 2005; MACHADO et al., 2020). Due to its rapid growth the application of synthetic phytosanitary products (NOACK et al., 2009; MACHADO et al., 2016; WILCKEN et al., 2019), biological control (WILCKEN et al., 2010; MASCARIN et al., 2012; BARBOSA et al., 2017; LORENCETTI et al., 2018; SOLIMAN et al., 2019; WILCKEN et al., 2019), and the use of alternative products (LORENCETTI et al., 2015) have been investigated to control this species.

According to SMITH (1996), the use of alternative products such as essential oils can induce the production of key enzymes involved in the synthesis of lignin and phytoalexins, such as peroxidase, polyphenoloxidase and phenolic compounds, capable of activating or inducing resistance responses in plants. This approach represents an alternative strategy for the control of $T$. peregrinus as well as other pests or pathogens.

Knowledge of the plant defense routes involving the activation of secondary metabolites in the induction of resistance is indispensable for studies of new products to control diseases and insects. However, tests on resistance induction in eucalyptus are rare, especially with essential oils as inductors and the studies already realized with other species (RODRIGUES et al., 2006; COUTO et al., 2009; DEBONA et al., 2009; MORAES et al., 2009; BARROS, 2011) only had results evaluated few days after induction, demonstrating to be necessary to observe if this effect can be permanent.

This work evaluated the effects of essential oils of M. alternifolia, C. sylvestris and E. uniflora on the defense mechanisms of $E$. benthamii seedlings against an insect pest.

\section{MATERIALS AND METHODS}

Four-month-old seedlings of E. benthamii were obtained from the commercial nursery Golden
Tree Reforestation Company and they were brought to the Universidade Tecnológica Federal do Paraná - Câmpus Dois Vizinhos, Unidade de Ensino e Pesquisa em Viveiro de Mudas. They were kept in a greenhouse and irrigated via a sprinkler eight times by day for 30 minutes.

The seedlings were evaluated for their total height, diameter of breast height (DBH), at height 15 $\mathrm{cm}$ and number of leaves with the objective of using a standardized material. The experimental design consisted of four treatments with four replications, containing 20 seedlings by plot.

Essential oils of $M$. alternifolia, $C$. sylvestris and E. uniflora with a concentration of $100 \%$ were obtained from the Garden City of Ibiúna, SP. They had been extracted via steam dragging, packed in amber glass bottles and refrigerated (Brastemp ${ }^{\circledR}$ ) at $\pm 4{ }^{\circ} \mathrm{C}$ until use. Essential oil of $M$. alternifolia contains 1,8-cineol (72,31\%), a-terpineol (8,55\%) and a-thujone $(6,1 \%)$, while that of $C$. sylvestris contains g-muurolene $(19,55 \%)$, a-zingiberene $(15,24 \%)$ and s-amorphene $(13,17 \%)$. Essential oil of E. uniflora contains calamen-10-ene $(20,21 \%)$, silfiperferol-6em-5-one $(10,06 \%)$ and germacrone $(6,61 \%)$.

The elicitor potential of essential oils of $M$. alternifolia, C. sylvestris and E. uniflora on E. benthamii, at the concentration of $0.75 \%$ adjusted in sterilized distilled water were evaluated. For the control, sterile distilled water and Tween $80^{\circledR}(0.01 \%)$ was used.

Of each solution, $4 \mathrm{~mL}$ were manually sprayed on each E. benthamii seedling to reach the point of drainage. Two bioassays were carried out, first, spraying at 30 days after receiving the material, with the evaluation performed 30 days after treatment and; the second, spraying at seven days after the first analysis, with evaluations after tree days. In both bioassays, the biochemical analyzes of the foliar tissues were carried out on total sugars, total proteins, peroxidases, PAL, and phenols.

The concentrations of total sugars were determined by the phenol sulfuric method described by DUBOIS et al., (1956). For this, $1 \mathrm{~g}$ of leaf tissue was used, and the total sugars concentration was determined via a standard glucose curve. Protein quantification was performed by the method of BRADFORD (1976). Leaf tissue samples of $1 \mathrm{~g}$ were used and the extract was analyzed by a spectrophotometer at $630 \mathrm{~nm}$ to obtain the absorbance value. Extraction and determination of peroxidase were performed according to MATSUNO \& URITANI (1972); absorbance was measured at 450 $\mathrm{nm}$ in a spectrophotometer.

The PAL activity was determined via colorimetric quantification of the trans-cinnamic 
acid released from the substrate phenylalanine, using a spectrophotometer at $290 \mathrm{~nm}$ according to the methodology described by RODRIGUES et al. (2006).

The determination of total phenols was carried out in two stages, following the method adapted from BIELESKI \& TURNER (1966). In the first phase, approximately $1 \mathrm{~g}$ of leaf tissue was macerated at room temperature with $4 \mathrm{~mL}$ of the MCA solution (methanol, chloroform, water 6/2.5/1.5, $\mathrm{v} / \mathrm{v} / \mathrm{v}$ ), packed in Eppendorf tubes, and centrifuged at $6000 \mathrm{rpm}$ at $20{ }^{\circ} \mathrm{C}$ for $20 \mathrm{~min}$. Subsequently, the total supernatant was collected, and a further extraction of the remaining residue was carried out, adding $4 \mathrm{~mL}$ of MCA, vortexed, and centrifuged again at $6000 \mathrm{rpm}$ for $20 \mathrm{~min}$. The supernatant was added to the previously collected supernatant and the obtained extract was spiked with $1 \mathrm{~mL}$ of chloroform and $1.5 \mathrm{~mL}$ of distilled water, followed by centrifugation at $6000 \mathrm{rpm}$ (15 min). The second stage comprised the determination of total phenols, performed by the method adapted from JENNINGS (1991). The samples were prepared from a $0.5 \mathrm{~mL}$ aliquot from the top of the phenol extraction tube (MCA extract) and $0.5 \mathrm{~mL}$ of distilled water and 0.5 $\mathrm{mL}$ of diluted Folin Ciocalteau reagent 1:10 (v/v) were added. After $15 \mathrm{~min}, 5 \mathrm{~mL}$ of the alkaline reagent " $A$ " (prepared with $2 \%$ sodium carbonate in $0.1 \mathrm{~N}$ sodium hydroxide solution) were added and after $50 \mathrm{~min}$, absorbance was read at $760 \mathrm{~nm}$ in a spectrophotometer (model SP-2000UV-Spectrum). The result was expressed as $\mathrm{mg} \cdot \mathrm{g}^{-1}$ fresh tissue. Quantification of phenols was performed using a standard curve with tyrosine.

The data were submitted to the normality test of Lilliefors. The data were transformed to total sugars, proteins, peroxidase, PAL, and phenols for the bioassay at 30 days and for phenols for the bioassay at 3 days, according to the square root of $x+1$. Subsequently, the transformed data were submitted to analysis of variance (ANOVA), followed by the Duncan test at $5 \%$ of probability, using the Genes ${ }^{\circledR}$ software.

\section{RESULTS AND DISCUSSION}

The essential oils of $M$. alternifolia, $C$. sylvestris, and E. uniflora, sprayed on E. benthamii seedlings analyzed after 30 days had no significant effect on total sugars, proteins, peroxidase, PAL activity and phenols (Table 1). This showed that the defense-inducing effect is not permanent, since, on day 3 after the application, it was obtained opposite results, with significant effect of these treatments on the same variables mentioned, except for phenols (Table 2).

Most of the studies (RODRIGUES et al., 2006; COUTO et al., 2009) carried out using pathogen resistance inducers evaluated the defense metabolic activity within few days after induction, as it may not remain in the plant for an extended period. It is worth mentioning that most of these works (DEBONA et al., 2009; MORAES et al., 2009; BARROS, 2011) involved annual crops, while for perennial species, such as eucalyptus, the patterns could be different.

After spraying pathogen resistance inducers, the rates of plant protein production are expected to increase because of the triggering of defense gene expression, which it was observed after the application of oils of M. alternifolia, C. sylvestris and E. uniflora. This demonstrated that the metabolic behavior of the plants has been altered. A statistically significant increase in the activity of the PAL defense enzyme was observed for the control and treatment with $M$. alternifolia and C. sylvestris essential oils (Table 2).

Casearia sylvestris contains terpenes and triterpenes, steroids or triterpenoids, flavonoids, fatty acids and anthocyanosides in its leaves. The

Table 1 - Concentrations of total sugars $\left(\mathrm{mg} \cdot \mathrm{g}^{-1}\right)$, proteins $\left(\mathrm{mg} \cdot \mathrm{g}^{-1}\right)$, peroxidase $\left(\mathrm{mg} \mathrm{g}^{-1}\right)$, phenylalanine ammonia - PAL $(\mathrm{UAbs} / \mathrm{min} / \mathrm{mg}$ ptna), and phenols (mg. $\mathrm{g}^{-1}$ ) in Eucalyptus benthamii seedlings sprayed with essential oils of Melaleuca alternifolia, Casearia sylvestris, and Eugenia uniflora and evaluated after 30 days.

\begin{tabular}{lccccc}
\hline Treatment & Total sugars $\left(\mathrm{mg} . \mathrm{g}^{-1}\right)$ & Proteins $\left(\mathrm{mg} \cdot \mathrm{g}^{-1}\right)$ & Peroxidase $\left(\mathrm{mg} \cdot \mathrm{g}^{-1}\right)$ & PAL (UAbs/min/mg ptna) & Phenols $\left(\mathrm{mg} . \mathrm{g}^{-1}\right)$ \\
\hline Control & $4.39 \pm 041^{\mathrm{ns}}$ & $0.16 \pm 0.012^{\mathrm{ns}}$ & $41.80 \pm 2.11^{\mathrm{ns}}$ & $1.19 \pm 0.142^{\mathrm{ns}}$ & $31.99 \pm 5.39^{\mathrm{ns}}$ \\
M. alternifolia & $6.47 \pm 071$ & $0.19 \pm 0.006$ & $46.09 \pm 5.16$ & $1.12 \pm 0.161$ & $24.67 \pm 1.76$ \\
C. sylvestris & $4.82 \pm 0.29$ & $0.17 \pm 0.011$ & $38.50 \pm 4.18$ & $1.02 \pm 0.141$ & $24.41 \pm 0.75$ \\
E. uniflora & $6.04 \pm 0.85$ & $0.18 \pm 0.017$ & $41.26 \pm 3.04$ & $0.89 \pm 0.106$ & 6.68 \\
CV \% & 23.68 & 13.94 & 18.18 & $22.61 \pm 1.70$ \\
\hline
\end{tabular}

$\mathrm{ns}-$ not significant by the $\mathrm{F}$ test at the $5 \%$ probability of error level. 
Table 2 - Concentrations of total sugars $\left(\mathrm{mg} \cdot \mathrm{g}^{-1}\right)$, proteins $\left(\mathrm{mg} \cdot \mathrm{g}^{-1}\right)$, peroxidase $\left(\mathrm{mg} \cdot \mathrm{g}^{-1}\right)$, phenylalanine ammonia - PAL $(\mathrm{UAbs} / \mathrm{min} / \mathrm{mg}$ ptna), and phenols mg. $\mathrm{g}^{-1}$ ) in Eucalyptus benthamii seedlings sprayed with essential oils of Melaleuca alternifolia, Casearia sylvestris, and Eugenia uniflora and evaluated after 3 days.

\begin{tabular}{|c|c|c|c|c|c|}
\hline Treatment & Total sugars (mg.g $\left.{ }^{-1}\right)$ & Proteins $\left(\mathrm{mg} \cdot \mathrm{g}^{-1}\right)$ & Peroxidase $\left(\mathrm{mg} \cdot \mathrm{g}^{-1}\right)$ & PAL (UAbs/min/mg ptna) & Phenols (mg.g $\mathrm{g}^{-1}$ ) \\
\hline Control & $4.05 \pm 0.77 b$ & $0.06 \pm 0.010 \mathrm{~b}$ & $43.45 \pm 4.19 b$ & $3.63 \pm 0.75 a$ & $24.97 \pm 1.32^{\mathrm{ns}}$ \\
\hline M. alternifolia & $7.35 \pm 0.67 a$ & $0.10 \pm 0.009 a$ & $52.56 \pm 1.68 \mathrm{ab}$ & $1.96 \pm 0.22 \mathrm{ab}$ & $25.69 \pm 0.75$ \\
\hline C. sylvestris & $4.93 \pm 0.12 b$ & $0.09 \pm 0.008 \mathrm{ab}$ & $58.11 \pm 3.10 \mathrm{a}$ & $2.02 \pm 0.14 \mathrm{ab}$ & $27.56 \pm 0.75$ \\
\hline E. uniflora & $7.92 \pm 0.89 a$ & $0.11 \pm 0.002 \mathrm{a}$ & $63.39 \pm 1.70 \mathrm{a}$ & $1.66 \pm 0.10 b$ & $26.42 \pm 0.41$ \\
\hline $\mathrm{CV} \%$ & 22.46 & 18.33 & 10.55 & 10.47 & 3.21 \\
\hline
\end{tabular}

ns - not significant by the F test at the $5 \%$ probability of error level.

species $M$. alternifolia has high economic interest due to the presence of essential oils stored in the leaf tissue (VIEIRA et al., 2004), containing terpenes and monoterpenes, naturally occurring substances that induce resistance (BROPHY \& DORAN, 2004). However, it needs to be verified whether this expression can inhibit the activity of $T$. peregrinus in the nursery. CAMPOS et al. (2003) observed that bean plants treated with salicylic acid triggered PAL gene expression by activating plant defense routes. Similarly, LORENCETTI et al. (2015) observed that the alternative products Rotenat $\mathrm{CE}^{\circledR}$ and Topneem ${ }^{\circledR}$ acted as inductors of resistance in soy cotyledons, expressing high values of PAL activity.

The higher levels of PAL may be due to the lower concentrations of total sugars obtained, probably triggering plant stress due to the lack of photoassimilates, enabling the production of defense compounds.

The enzyme PAL allowed the expression of several compounds such as lignin, flavonoids (anthocyanins), phytoalexins, and salicylic acid (VERMERRIS \& NICHOLSON, 2006; EMILIANI et al., 2009), which they are responsible for the survival of the plant under stress, which triggers the transcription of the messenger RNA that encodes PAL, increasing its amount in the plant and thereby stimulating the synthesis of phenolic compounds (CHITARRA \& CHITARRA, 2005).

The increase in total sugar levels after 3 days of the spraying of essential oils, $M$. alternifolia and E. uniflora (Table 2), is directly involved in primary plant metabolism. Sugars are substrates of secondary metabolism, sustaining the production of phenolic compounds via the phenylpropanoids. We assumed that their lack may have triggered a specific route, in this case, PAL production, caused by internal stress.
We hypothesized that the production of PAL in the control was stimulated because of the possible production of volatile salicylates released by nearby plants treated with essential oils. These volatiles can reach plants at long distances from the emitting source, acting on the systemic responses acquired of these plants to activate the chemical defense routes (HEIL \& TON, 2008).

The application of E. uniflora and $C$. sylvestris oils resulted in higher peroxidase values when compared with the control (Table 2). Peroxidase is an enzyme present in microorganisms, plants, and animals, where it catalyzes the oxidation of hydrogen and its reducers. Some peroxidases are induced during stress caused by pathogens (HIRAGA et al., 2001). Peroxidases oxidize organic substrates through the elimination of hydrogen peroxide, reactive oxygen species and electron acceptors. They also play an important role in plant growth and development, cellular detoxification and, defense mechanisms such as wound healing and phenolic compound oxidation (BAYSAL et al., 2003) and impact the final polymerization of lignin, oxidizing the hydroxyls of phenolic groups. Changes in peroxidase activity have often been correlated with the potential contribution of plant protection (PASCHOLATI, 2011; PINTO et al., 2011; STANGARLIN et al., 2011).

This result does not rule out the possibility of using E. uniflora oils as a defense inducer for eucalyptus seedlings, since it triggered an increase in one of the defense routes. For example, E. uniflora essential oil has the potential to induce the phytoalexin glyceoline in cotyledons of Glicine max (soy bean) (SCHWANESTRADA et al., 2000; MAZARO et al., 2008).

In general, the oil of E. uniflora had the highest impact on all variables at 3 days after application (Table 1), most likely because of the highest total sugar 
content obtained, which it was also observed for $M$. alternifolia in total sugars and proteins. The elevation of total sugars may be related to the increased metabolic activity of the induced plants, since the metabolic cycles are integrated and the induction of compounds of the secondary metabolism can affect the primary metabolism of carbon, such as glycolysis as well as pentose phosphate or citric acid cycle.

These results are in agreement with those reported by TANG et al. (1996) for Arabidopsis thaliana (L. Heynh.) on leaves infected by Albugo candida, where there was an increase in the total sugar concentration. In young plants of Shizolobium amazonicum (Huber ex Ducke) and $S$. parahyba (Huber ex Ducke) (guapuruvu) submitted to two cycles of water deficiency, an increase in total sugar content was observed (CARVALHO, 2005). Different stress situations, including pathogen attacks, cause direct or indirect accumulation of total sugars (ROITSCH, 1999).

\section{CONCLUSION}

The essential oils of $M$. alternifolia and C. sylvestris have potential as inducers of defense mechanisms on $E$. benthamii seedlings after 3 days of their application, what it demonstrated not be permanent.

\section{ACKNOWLEDGMENTS}

To Brazilian Conselho Nacional de Desenvolvimento Científico e Tecnológico $(\mathrm{CNPq})$ for the grant to MP for the project (Process 422269/2016-6). The CNPq for providing scholarships to GL, GOV, and LTA. The CNPq provided a scholarship to AWJ and MP, and the Coordenação de Aperfeiçoamento de Pessoal de Nível Superior (CAPES) provided a scholarship to LDS. To Universidade Tecnológica Federal do Paraná (UTFPR) for supporting this study.

\section{DECLARATION OF CONFLICT OF INTEREST}

The authors declare that there is no conflict of interest that could constitute an impediment to the publication of this article.

\section{AUTHORS' CONTRIBUTIONS}

LDS, AWJ and MP conceived and designed experiments. LDS, JZ, GL, GVO and LTA performed the experiments, and carried out the lab analyses. AWJ, MP and ERL supervised and coordinated the experiments. LDS, AWJ, ERL, GL and MP prepared the draft of the manuscript. All authors critically revised the manuscript and approved of the final version.

\section{REFERENCES}

BARBOSA, L. R. et al. Establishment in the Field of Cleruchoides noackae (Hymenoptera: mymaridae), an exotic egg parasitoid of Thaumastocoris peregrinus (Hemiptera). Florida
Entomologist, v.100, n.2, p.372-374, 2017. Florida Entomological Society. Available from: <https://bioone.org/journals/floridaentomologist/volume-100/issue-2/024.100.0237/Establishmentin-the-Field-of-Cleruchoides-noackae-Hymenoptera-Mymaridae/10.1653/024.100.0237.full>. Accessed: May, 21, 2019. doi: http: 10.1653/024.100.0237.

BARROS, R. Study on the foliar application of acibenzolars-methyl to induce resistance to Asian rust in soybeans and cercosporiosis in corn. Arquivos do Instituto Biológico, v.78, n.4, p.519-528, 2011.

BAYSAL, O. et al. Induction of defence-related enzymes and resistance by the plant activator acibenzolar-S-methyl in tomato seedlings against bacterial canker caused by Clavibacter michiganensis ssp. Michiganensis. Plant Pathology, v.52, p.747753, 2003. Available from: <https://onlinelibrary.wiley.com/doi/ful 1/10.1111/j.1365-3059.2003.00936.x>. Accessed: May, 21, 2019. doi: 10.1111/j.1365-3059.2003.00936.x.

BIELESKI, R. L.; TURNER, N. A. Separation and estimation of amino acids in crude plant extracts by thin-layer electrophoresis and chromatography. Analitycal Biochemistry, v.17, p.278-293, 1966. Available from: $<$ https://www.sciencedirect.com/science/article/ pii/0003269766902065?via\%3Dihub>. Accessed: May, 21, 2019. doi: 10.1016/0003-2697(66)90206-5.

BRADFORD, M. M. A rapid and sensitive method for the quantification of microgram quantities of protein utilizing the principle of protein-dye binding. Analytical Biochemistry, v.72, p.248-254, 1976. Available from: <https://www.sciencedirect.com/ science/article/pii/0003269776905273>. Accessed: May, 21, 2019. doi: 10.1016/0003-2697(76)90527-3.

BROPHY, J. J.; DORAN, J. C. Geographic Variation in Oil Characteristics in Melaleuca ericifolia. Journal of Essential Oil Research, v.16, p.4-8, 2004. Available from: <https://www. tandfonline.com/doi/abs/10.1080/10412905.2004.9698635>. Accessed: May, 21, 2019. doi: 10.1080/10412905.2004.9698635.

CAMPOS, Â. D. et al. Induction of chalcone synthase and phenylalanine ammonia-lyase by salicylic acid and Colletotrichum lindemuthianum in common bean. Brazilian Journal of Plant Physiology, v.15, p.129-134, 2003.

CARPINTERO, D. L.; DELLAPÉ, P. M. A new species of Thaumastocoris Kirkaldy from Argentina (Heteroptera: Thaumastocoridae: Thaumastocorinae). Zootaxa, n.1228, p.61-68, 2006. Available from: <https://www.biotaxa.org/Zootaxa/article/ view/zootaxa.1228.1.4>. Accessed: May, 20, 2019. doi: 10.11646/ zootaxa.1228.1.4.

CARVALHO, C. J. R. Plant responses of Schizolobium amazonicum [S. parahyba var. amazonicum] and Schizolobium parahyba [Schizolobium parahybum] to water deficiency. Revista Árvore, v.29, n.6, p.907-914, 2005. Available from: $<$ http://www.scielo.br/scielo.php?script=sci_arttext\&pid=S010067622005000600009\&lng=en\&nrm=iso >. Accessed: Jul. 9, 2017. doi: 10.1590/S0100-67622005000600009.

CASTIGLIONE, E. et al. First record from Calabria (southern Italy) of the "bronze bug" Thaumastocoris peregrinus Carpintero \& Dellapé, 2006, alien Eucalyptus pest native to Australia (Hemiptera: heteroptera. Journal Of Entomological And Acarological Research, v.52, n.1, p.15-18, 2020. PAGEPress Publications. Available from: <https://www.pagepressjournals.org/index.php/jear/article/

Ciência Rural, v.51, n.9, 2021. 
view/8879>. Accessed: Jul. 9, 2017. doi: 10.4081/jear.2020.8879. CHITARRA, M. I.; CHITARRA, A. B. Postharvest of fruits and vegetables: Physiology and handling. Lavras: UFLA 2005.

COUTO, E.F. et al. Postharvest of fruits and vegetables: Physiology and handling Evaluation of resistance inducers in cotton to fusarium wilt: enzymatic activity and infection index. Tropical Plant Pathology, v.34, p.352-356, 2009.

DEBONA, D. et al. Effect of seed treatment with fungicides and acibenzolar-S-methyl on the control of Asian rust and seedling growth in soybean cultivars. Summa Phytopathol, v.35, n.1, p.26-31, 2009. Available from: <http://www.scielo. br/scielo.php?pid=S0100-54052009000100004\&script $=$ sci abstract\&tlng $=\mathrm{pt}>$. Accessed: May, 20, 2019. doi: 10.1590/S010054052009000100004

DUBOIS, M. et al. Colorimetric method for determination of sugars and related substances. Analitycal Biochemistry, v.28, p.350-356, 1956. Available from: <https://pubs.acs.org/doi/ abs/10.1021/ac60111a017>. Accessed: May, 20, 2019. doi: 10.1021/ac60111a017.

EMILIANI, G. et al. A horizontal gene transfer at the origin of phenylpropanoid metabolism: a key adaptation of plants to land. Biology Direct, v.4, n.7, p.1-12, 2009. Available from: <https:// biologydirect.biomedcentral.com/articles/10.1186/1745-6150-4-7>. Accessed: May, 20, 2019. doi: 10.1186/1745-6150-4-7.

HEIL, M.; TON, J. Long-distance signalling in plant defence. Trends in Plant Science, v.13, n.6, p.264-272, 2008. Available from: <https://www.ncbi.nlm.nih.gov/pubmed/18487073>. Accessed: May, 20, 2019. doi: 10.1016/j.tplants.2008.03.005.

HIRAGA, S. et al. A large family of class III plant peroxidases. Plant and Cell Physiology, v.42, n.5, p.462-468, 2001. Available from: <https://www.researchgate.net/publication/11955797_A large_family_of_Class_III_plant_peroxidases $>$. Accessed: May, 20, 2019. doi: $10.1093 / \mathrm{pcp} / \mathrm{pce} 061$.

IBÁ. Indústria brasileira de árvores. Brasília, DF. IBÁ, p.80, 2015.

IDE, S. et al. Deteccion de Thaumastocoris peregrinus (Heteroptera: Thaumastocoridae) associado a Eucalyptus spp. en Chile. Bosque, v.32, p.309-313, 2011. Available from: $<$ https://scielo.conicyt.cl/scielo.php?script=sci arttext\&pid $=$ S0717-92002011000300012 $>$. Accessed: May, 20, 2019. doi: 10.4067/S0717-92002011000300012.

GARCIA, A. et al. First record of Thaumastocoris peregrinus in Portugal and of the neotropical predator Hemerobius bolivari in Europe. Bulletin of Insectology, v.66, n.2, p.251-256, 2013.

JACOBS, D. H.; NESER, S. Thaumastocoris australicus Kirkaldy (Heteroptera: Thaumastocoridae): a new insect arrival in South Africa, damaging to Eucalyptus trees: research in action. South African Journal of Science, v.101, p.233-236, 2005.

JENNINGS, A. C. The determination al dihydroxy phenolic compounds in extracts of plant tissues. Analytical Biochemistry, v.118, p.396-398, 1991. Available from: <https://www. sciencedirect.com/science/article/pii/000326978190600X >. Accessed: May, 20, 2019. doi: 10.1016/0003-2697(81)90600-X.

JIMNEZ-QUIROZ, E. et al. First Record of the Bronze Bug, Thaumastocoris peregrinus CARPINTERO \& DELLAPÉ
2006 (Hemiptera: Thaumastocoridae), in Mexico. Journal of Agricultural and Urban Entomology, n.32, p.35-39, 2016. Available from: <https://doi.org/10.3954/1523-5475-32.1.35>. Accessed: May, 20, 2019. doi: 10.3954/1523-5475-32.1.35.

LORENCETTI, G. A. T. et al. Alternative Products for Control of Thaumastocoris peregrinus and Resistance Induction in Plants. Floresta Ambient, v.22, n.4, p.541-548, 2015. Available from: $<$ https://www.scielo.br/scielo.php?script=sci abstract\&pid $=$ S2 $179-80872015000400541 \& \operatorname{lng}=$ pt\&nrm $=$ iso $>$. Accessed: May, 20, 2019. doi: 10.1590/2179-8087.066913.

LORENCETTI, G. A. T. et al. Efficiency of Beauveria bassiana Vuill. and Isaria sp. for the control of Thaumastocoris peregrinus Carpintero \& Dellapé (Hemiptera: thaumastocoridae). Ciência Florestal, v.28, n.1, p.403-411, 2018. Universidad Federal de Santa Maria. Available from: <https://periodicos.ufsm.br/ cienciaflorestal/article/view/31612>. Accessed: May, 20, 2019. doi: $10.5902 / 1980509831612$

MACHADO, D. do N. et al. Insecticide Evaluation in the Control of Thaumastocoris peregrinus (Hemiptera: Thaumastocoridae). Floresta e Ambiente, v.23, n.2, p.245250,2016 . Available from: <http://www.scielo.br/scielo. php?script $=$ sci_arttext\&pid $=$ S2 179-80872016000200245\&ln $\mathrm{g}=\mathrm{pt} \&$ tlng $=\mathrm{pt}>$. Accessed: May, 14, 2019. doi: 10.1590/21798087.144415

MACHADO, D. do N. et al. The ongoing dispersion of the Eucalyptus bronze bug (Thaumastocoris peregrinus) in Spain. Forest Systems, v.28, n.3, p.1-8, 2019. Instituto Nacional de Investigacion y Tecnologia Agraria y Alimentaria (INIA). Available from: $\quad<$ https://revistas.inia.es/index.php/fs/article/view/15353>. Accessed: May, 14, 2019. doi: 10.5424/fs/2019283-15353.

MACHADO, D. do $\mathrm{N}$. et al. One maternal lineage leads the expansion of Thaumastocoris peregrinus (Hemiptera: thaumastocoridae) in the new and old worlds. Scientific Reports, v.10, n.1, p.1-12, 2020. Springer Science and Business Media LLC. Available from: <https://www.nature.com/articles/s41598-02060236-7>. Accessed: May, 14, 2019. doi: 10.1038/s41598-02060236-7.

MARTÍNEZ, G.; BIANCHI, M. Primer registro para Uruguay de la chinche del eucalipto, Thaumastocoris peregrinus Carpintero y Dellappé, 2006 (Heteroptera: Thaumastocoridae) Agrociência, v.14, p.15-18, 2010.

MASCARIN, G. M. et al. Natural occurrence of Zoopththora radicans (Entomophthorales: Entomophthoraceae) on Thaumastocoris peregrinus (Heteroptera: Thaumastocoridae) na invasive pest recently found in Brazil. Journal of Invertebrate Pathology, v.110, p.401-404, 2012. Available from: <http:// europepmc.org/abstract/med/22490879>. Accessed: May, 20, 2019. doi: 10.1016/j.jip.2012.03.025.

MATSUNO, H.; URITANI, I. Physiological behavior of peroxidase isozymes in sweet potato root tissui injured by cutting or with black rot. Plant \& Cell Physiology, v.23, p.1091-1101, 1972. Available from: <https://academic.oup.com/pcp/article-abstract/13/6/1091/1 881177? redirectedFrom=fulltext $>$. Accessed: May, 20, 2019. doi: 10.1093/oxfordjournals.pcp.a074815.

MAZARO, S. M. et al. Phytoalexins induction in soy cotyledons in response to pitangueira leaf derivatives. Ciência Rural, v.38, n.7, p.1824-1829, 2008. Available from: <http://www.scielo. 
br/scielo.php?pid $=$ S0103-84782008000700004\&script $=$ sci abstract\&tlng=pt $>$. Accessed: May, 20, 2019. doi: 10.1590/S010384782008000700004 .

MORAES, J. C. et al. Inductors of resistance to the whitefly Bemisia tabaci biotype (Genn., 1889) (Hemiptera: Aleyrodidae) in soybean. Ciência e Agrotecnologia, v.33, n.5, p.1260-1264, 2009. Available from: <http://www.scielo.br/scielo.php?pid=S141370542009000500009\&script $=$ sci_abstract\&tlng $=$ pt $>$. Accessed: May, 20,2019. doi: 10.1590/S1413-70542009000500009.

NOACK, A. E. Efficacy of imidacloprid in the control of Thaumastocoris peregrinus on Eucalyptus scoparia in Sydney, Australia. Arboriculture \& Urban Forestry, v.35, p.191-195, 2009.

PASCHOLATI, S. F. Physiology of Parasitism: How Plants Defend Against Pathogens. In: BERGAMIN FILHO, et al. (Ed.). Manual de Fitopatologia I: Princípios e Conceitos. Agronômica Ceres, v.35. p.593-636, 2011.

PINTO, M. S. T. et al. The study of defense genes and proteins in plants. Revista Brasileira de Biociências, v.9, n.2, p.241-248, 2011.

RODRIGUES, A. A. C. et al. Induction of resistance to Fuzarium oxysporum f. sp. Tracheiphilum in cowpea: efficiency of abiotic inducers and elicited enzyme activity. Fitopatologia Brasileira, v.31, p.492-499, 2006. Available from: <http://www.scielo. $\mathrm{br} / \mathrm{scielo}$. php? pid $=\mathrm{S} 0100-41582006000500009 \& \mathrm{script}=\mathrm{sci}$ abstract\&tlng=pt $>$. Accessed: May, 20, 2019. doi: 10.1590/S010041582006000500009 .

ROITSCH, T. Source-sink regulation by sugar and stress. Current Opinion in Plant Biology, v.2, p.198-206, 1999. Available from: $<$ https://www.ncbi.nlm.nih.gov/pubmed/10375568>. Acessed: May, 20, 2019. doi: 10.1016/S1369-5266(99)80036-3.

SCHWAN-ESTRADA, K. R. F. et al. Use of plant extracts to control phytopathogenic fungi. Floresta, v.30, n.1-2, p.129-137, 2000.

SOPOW, S. et al. Bronze bug, Thaumastocoris peregrinus: a new Eucalyptus pest in New Zealand. Surveillance, v.39, n.2, p.43-46, 2012.

SMITH, C. J. Accumulation of phytoalexins: defense mechanisms and stimulus response system. The New Phytologist, v.132, p.1-
45, 1996. Available from: <https://nph.onlinelibrary.wiley.com/ doi/full/10.1111/j.1469-8137.1996.tb04506.x>. Accessed: May, 10, 2019. doi: $10.1111 /$ j.1469-8137.1996.tb04506.x.

SOLIMAN, E. P. et al. Susceptibility of Thaumastocoris peregrinus (Hemiptera: Thaumastocoridae), a Eucalyptus pest, to entomopathogenic fungi. Scientia Agricola, v.76, n.3, p.255-260, 2019. Available from: <http://www.scielo.br/scielo. php?script=sci_abstract\&pid=S0103-90162019001300255\&lng= pt\&nrm=iso $>$. Accessed: May, 10, 2019. doi: 10.1590/1678-992x2017-0043.

STANGARLIN, J. R. et al. Plant defense against phytopathogens. Scientia Agraria Paranaenis, v.10, n.1, p.18-46, 2011.

TANG, X.; et al. The effect of Albugo Candida (white blister rust) on the photosynthetic and carbohydrate metabolism of leaves of Arabidopsis thaliana. Plant, Cell and Environment, v.19, p.967975, 1996. Available from: <https://onlinelibrary.wiley.com/doi/ abs/10.1111/j.1365-3040.1996.tb00461.x>. Accessed: May, 12, 2019. doi: $10.1111 /$ j.1365-3040.1996.tb00461.x.

VERMERRIS, W.; NICHOLSON, R. Phenolic compound biochemistry. Dordrecht: Springer, 2006. 285p.

VIEIRA, T. et al. Nascimento. Constituintes químicos de Melaleuca alternifolia (Myrtaceae). Química Nova, v.27, n.4, p.536-9, 2004. Available from: <http://www.scielo.br/scielo. php? script $=$ sci_arttext\&pid $=$ S0100-40422004000400004>. Accessed: May, 12, 2019. doi: 10.1590/S010040422004000400004 .

WILCKEN, C. F. et al. Bronze bug Thaumastocoris peregrinus Carpintero \& Dellapé (Hemiptera: Thaumastocoridae) on Eucalyptus in Brazil and its distribution. Journal Research of Plant Protectio, v.50, p.184-188, 2010. Available from: <https:// repositorio.unesp.br/handle/11449/6119>. Accessed: May, 10, 2019. doi: $10.2478 / \mathrm{v} 10045-010-0034-0$.

WILCKEN, C. F. et al. Chemical vs entomopathogenic control of Thaumastocoris peregrinus (Hemiptera: thaumastocoridae) via aerial application in eucalyptus plantations. Scientific Reports, v.9, n.1, p.1-7, 2019. Springer Science and Business Media LLC. Available from: <https://www.nature.com/articles/s41598-019-45802-y>. Accessed: May, 10, 2019. doi: 10.1038/s41598-019-45802-y. 